\title{
9. THE IMPORTANCE OF THE DRAWING IN THE ARTISTIC CREATION PROCESS
}

Mircea Ştefănescu ${ }^{80}$

\begin{abstract}
In this academic paper I want to highlight the importance of the drawing and its purpose in the visual artist's creative effort which is in full artistic activity. I will illustrate what I have said previously with the drawings by artists such as Dürer Alfred, Alberto Giacometti, Henri de Toulouse-Lautrec, Andeea Paladio and others artists who have created numerous drawings to study, or as the remarkable artworks. So, during the artistic process the sculptors, the painters or the architects draw to study, to remember or to clarify their own ideas. Many drawings are straightforward, with a single-purpose and spontaneous, but often are an intuitive response to an experience or an idea which must be necessarily put on paper. These studies are often the means by which the artists develop passages which is meant to be incorporated in a detailed and complex art composition.
\end{abstract}

Key words: drawing, composition, spontaneous, creative effort, study

\section{Introduction}

The importance of drawing is essential and ever-present in the artistic creation process, and that's why it is very hard to define. Actually, the drawings are essentially linear and modest of size and these are made with a marking tool on a monochrome support. A wider definition would include the use of tonal surfaces supplementing or after circumstances, replace the linear elements, as well as reduced the use of polychrome variations both in line and tone. Even this expression can't include the reality of many artworks which should be regarded as drawings, by the consensus showed both the artists and art historians. In essence, the drawing is an two-dimensional art form characterized by the following factors: an element which produces signs used in a direct way, the color is limited, often one or two tones, and the paper which often is used as support. To define the drawing only based on physical properties would not grasp a basic truth about drawing. A greater importance for understanding the drawing is clarifying its purpose, what role it plays in the visual artist's creative effort which is in full artistic activity.

The sculptors, the painters and the architects draw constantly. They draw to study, to remember or to clarify their own ideas. They draw for pleasure, by moving a tool they produce a line which it likes to the eye and using the hand in a rhythmic and satisfactory activity. Many drawings are straightforward and spontaneous. Often, the drawings are an intuitive response to an experience or an idea which must be necessarily put on paper. And finally, there are those drawings which take the place alongside the fully realized artwork. Most of pretentious drawings represent a major effort for an artist which is considered them fully developed artworks. The drawings can be remarkable artworks and the public could feel free to enjoy them for the fulfillment of aesthetic ${ }^{80}$ Lecturer PhD., “George Enescu” National University of Arts from Iaşi, Romania, email:
mirstef68@yahoo.com 
sensations. Seen through this light, the drawings can quickly become the basis of an empathic connection between producer and consumer of visual art, full of the promise of reward aesthetic connection.

\section{The Drawing uses}

Both the drawing process and the sketches and detail drawings produced, it serve to the ultimate goal of the artist in various ways. The fast and flexible methods of drawer make it possible for the designer to transpose and visualize, by features skillful, the appearance of a three-dimensional object as it is seen from a vantage point chosen by cartoonist. Many drawings are straightforward, with a single-purpose and spontaneous, being an intuitive reaction to a suddenly encountered experience or an idea which the artist had to catch it from fly. In this moment the artist need to register a perception or an idea and he can find instant gratification in the act of drawing. When Alberto Giacometti felt the urge to make the drawing reproduced in Figure 1, he had available a tissue paper and a ballpoint pen.

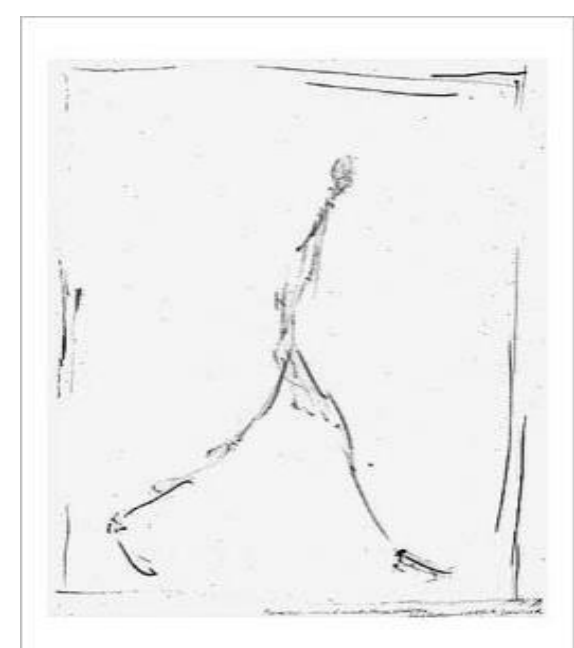

Fig. 1. Alberto Giacometti, Om mergând ${ }^{81}$

Another category of drawings, in direct contrast to quick sketch, comes from a slow and deliberate manipulation of a drawing material. The artist may devote for a rigorous drawing as a master as much time as he dedicates for a major composition like as a painting or a sculpture, in his desire to make a carefully and fully realized visual statement. Perhaps many of the drawings from the past were made to study a particular aspect of nature. The traditional subjects include human figure, animals, landscapes, flowers and individual plants, still life, drapery and architectural details. The drawing style is directly related to the material, but equally is important the artist's intention - what he sees or wants to communicate about its subject. The great German Renaissance master Albrecht Dürer showed an insatiable curiosity for nature and an immense desire to enrich its art by understanding the forms and functions of nature.

${ }^{81}$ http://www.theblurb.com.au/Issue69/Giacometti.htm, 10.03.2013 


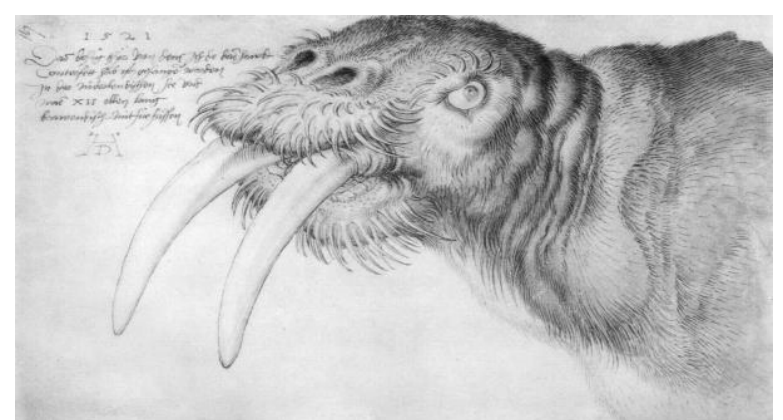

Fig.2. Albrecht Dürer, Cap de morsa (Knobler, 1983, fig. 226)

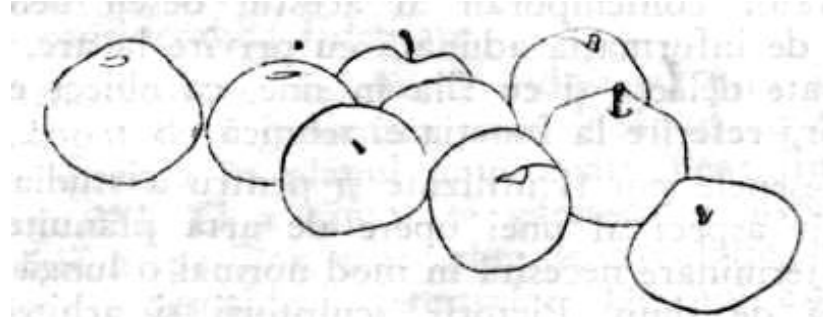

Fig.3. Ellsworth Kelly, Mere (Idem, p. 183)

That's why he filled his notebooks with sketches and a wide variety of detailed studies, registering both ordinary and unusual subjects. In 1521 it was captured a walrus near the Flemish coast; Figure 2 reproduces a sketch made by artist in pen and watercolor when the animal was examined. This curious drawing combines carefully the details observed whose shapes and features are decorative repeated, resulting an intensive and also very funny image. By means minimum contour line contemporary American artist Ellsworth Kelly made a still life with apples (Figure 3), which suggests not only the shape and volume of the fruit, but also a spatial ambience for subject. The approach to nature by Kelly is probably no less intense or analytical than Dürer but the process used by Ellsworth Kelly - simple pencil line - is relentless selective, which contrasts with the widespread development given of the shape and surface details by German maestro. The studies of figures which carefully traces the outward forms of the body (Figure 4.) expresses the detailed perceptions of an artist when he treats the body as a static object.

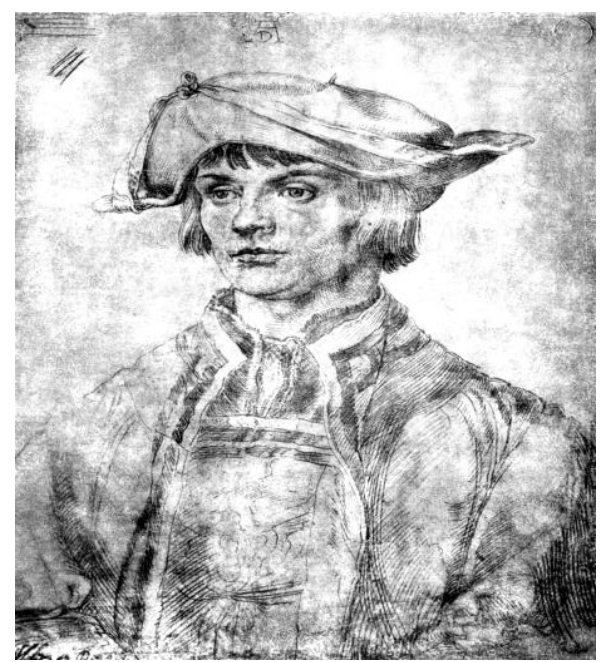

Fig.4. Albrecht Durer, Portretul lui Lucas van Layden ${ }^{82}$

${ }^{82}$ http://www.wikipaintings.org/en/albrecht-durer/portrait-of-lukas-van-leyden, 10.03.2013 
The architects have used the long time ago the drawing as a means to note the structure, the proportional relations and sculptural details of the edifice on which it admires. Figure 5 is a pen drawing by the architect Andrea Palladio, from the sixteenth century, which it analyzed the contours and dimensions of some portions of the Arch of Jupiter Ammon, from Verona, which is Roman building from fourth century. Its line is authoritative and accurate, but after all is spontaneous, which it is combined with numbers and notes written in an arbitrary arrangement on paper.

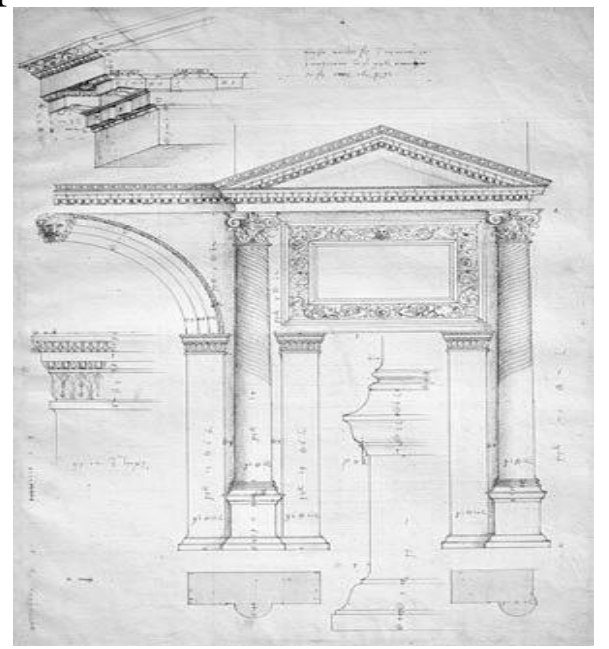

Fig.5. Andrea Palladio, Arcul lui Jupiter Ammon, Verona ${ }^{83}$

The drawings can also be used to study a particular aspect of a planned artwork which requires normally a long time to be finished and in this time the artist accumulates new experiences and knowledge. „Art can be studied in its many variations as manifested expression of diffrent cultural values, but also as a distinct structure of knowledge and experience" (Rusu, 2015). The painters, the sculptors and the architects draw to put on paper their own ideas. These studies are often the means by which the artists develop passages which is meant to be incorporated in a detailed and complex art composition. For most artists the drawing is a natural extension of their perceptual and rational processes. Each good drawer uses its own form of notation. „Like the handwriting, the drawing takes visual characteristics which it is resulted from the flow of ideas, from the unique rhythm of motor functions of the body and the personal traits of the drawer. Often these skills are combined with a symbolic shorthand which it is represented by objects, spaces and textures of the nature" (Ștefănescu, 2015, p. 24).

The visual style of the artist is the product of the combination between repetition of a limited vocabulary of symbols, original applications of the materials and the movements individualized of the arm, hand and the fingers which mark the paper. This style is often obvious throughout the artist's graphic work, but most strongly in sketches when lots of ideas encourages the spontaneity, unfettered desire to perform a complex and complete piece of art. The sketch is a form of observation and rapid notice of the main elements, of a

${ }^{83}$ http://pinterest.com/pin/540150549027752426, 10.03.2013 
subject, an attitude fleeting without the subject to model intentionally too long. Often the artists make the great compositions starting from a series of sketches or drawings which later they will redraws, giving birth to primary project which the artist will improve it until he get the final shape. There are drawings, which beyond any doubt, are the result of serious efforts made by the artist who believes that material is equal to any other. Within this category we can find so different productions such as the brush drawing by the Japanese artist Katsushika Hokusai. The Japanese respect the calligraphy as a major form of art. It is a compression art and the drawing is done in few minutes.

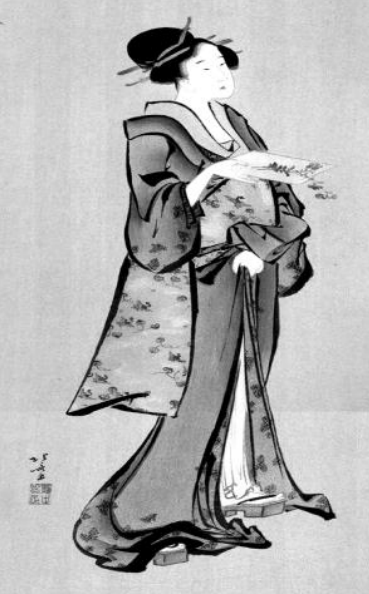

Fig.6. Katsushika Hokusai, Doamnă cu flori ${ }^{84}$

A discussion about drawing would be incomplete without a final clarification of the role which the drawing plays in other art forms. Often the painters draw on canvas using calligraphy to define an outline or to highlight an edge, sometimes to provide a detail in a larger form. Toulouse-Lautrec used in his artwork Cirque Fernando (Figure 7), free calligraphic line, in combination with flat color surfaces. Even the flat color surfaces reveals the artist's hand action, which he applied color in vigorous strokes, bringing with them another calligraphic element, more vague.

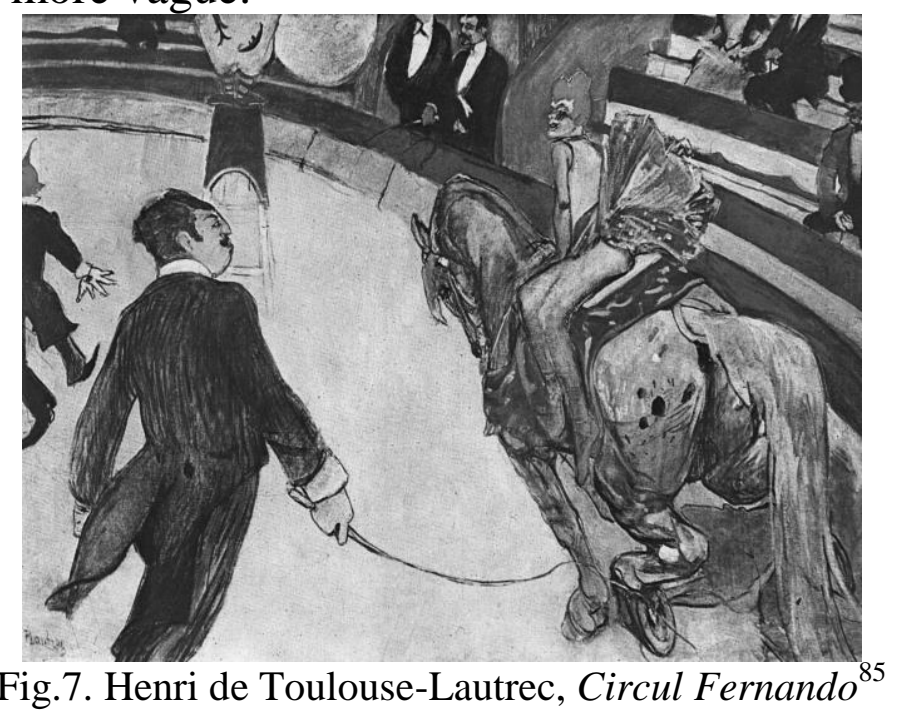

${ }^{84}$ http://www.baxleystamps.com/litho/sr/masterpieces_30_1925.shtml, 10.03.2013 


\section{Conclusions}

Numerous masterpieces containing drawn ${ }^{86}$ elements, however there is another sense larger, in which the drawing contributes at formation of artworks. Each line, each side produced or controlled by an artist is the result of a thought process - drawing. Whether it's a sign of ink on paper, the contact between two chromatic flat surfaces or outer limits of a metal plate cut by the flame, the artist must take the decisions which affecting the direction and length of linear motion during its training procedures. There is a difference between the drawing process and drawings. The drawing process is the operation to make decisions which controls lines, edges and proportional relations between forms and artworks and it differs from decisions involved in choosing the colors and variables of the surface. In such manner the artist draws whenever he works even if he could take another decisions in the same time.

The drawings offer the ability to intuit the nature of open options for the artist, and actually this openness and clarity attracts admirers and collectors to the drawings exhibitions. For many people, the emotion stimulated by drawings can't be matched by the effect of any other visual arts. There is great potential of aesthetic response to an artwork which the viewer is tickled to feel that he shares an intimate moment with the artist which produced it, which gives them a great satisfaction.

\section{Bibliography}

1. Argan, G. C. (1982). Arta modernă (2nd vol.). București: Meridiane.

2. Arnheim, R. (1979). Arta şi percepţia vizuală. București: Meridiane.

3. Bachellard, G. (2003). Poetica spaţiului. Pitești: Parelela 45.

4. Baraschi, C. (1962). Tratatul de Sculptura (Vols. 1-2). Bicurești: Meridiane.

5. Bartos, J. (2005). Structuri compoziţionale. Iași: Artes.

6. Besançon, A. (1996). Imaginea interzisă. București: Humanitas.

7. Blanc, C. (1876). Grammaire des arts du dessin. Paris: Librairie Renouard.

8. Burckhardt, J. (1987). Artă și istorie. București: Meridiane.

9. Cassou, J. (1971). Panorama artelor plastice contemporane (Vols. 1-2). București: Meridiane.

10. Covătaru, D. (2006). Simbol şi obiect în sculptură. Iaşi: Artes.

11. Duby, G. \& Daval, J.L. (2006). Sculptura din antichitate până în zilele noastre. Kohl: Taschen GmbH.

12. Dumitrescu, Z. (1988). Leonardo Structuri Geometrico-Plastice. București: Meridiane.

13. Durand, G. (1999). Figuri mitice şi chipuri ale operei. București: Nemira. 14. Eco, U. (2005). Opera deschisă. Pitești: Parelela 45.

\footnotetext{
${ }^{85} \mathrm{http}: / /$ www.wikipaintings.org/en/henri-de-toulouse-lautrec/at-the-circus-fernando-the-rider-1888, 10.03.2013

${ }^{86}$ Drawings are fotografismele Vasarely - cellophane or plexiglass surfaces - that separation by a few centimeters, plus spectator movement before them, giving rise to one aspect of Op Art's ... View Ioana Olaru Iulia, Science and art - Op Art site: techniques and materials, in vol. international Symposium of the Association of cultural and scientific Vasile Pogor, Iasi, universe sciences, Iasi, Ed. D \& T, 2010, ISBN 978-6-0657666-1-7, p. 71
} 
15. Focillon, H. (1977). Viaţa formelor. București: Meridiane.

16. Ghiţescu, Gh. (1979). Antropologie artistică. București: Editura Didactică şi Pedagogică.

17. Gottfried, B. (1982). Der nackte Mensch. Dresda: Veb Verlang der Kunst.

18. Gottfried, B. (1989). Wir zeichnen den menschen. Berlin: Volk und Wissen Volkseigener Verlag.

19. Huyghe, R. (1981). Dialog cu vizibilul. București: Meridiane.

20. Huyghe, R. (1971). Puterea imaginii. București: Meridiane.

21. Ingres, J. D. (1957). Écrits sur L'art. Paris: La jeune parque.

22. Knobler, N. (1983). Dialogul vizual. București: Meridiane.

23. Marleau, P. M. (2001). Fenomenologia percepției. București: Aion.

24. Olaru, I. I. (2010). Știinţă și artă - Op Art-ul: tehnici și materiale. In Universul ştiinţelor. Volumul Simpozionului internaţional al Asociaţiei culturalştiinţifice "Vasile Pogor", Iaşi: D\&T.

25. Olinescu, M. R. (2008). Biologia și psihologia artei. Bucrești: Cermaprint.

26. Pașca, E. M. (2013). Arts and inter/cultural education in the European School. Review of Artistic Education, 6, 45-56.

27. Rusu M. (2015). Intercultural Study of Art - Contemporary dimension. Review of Artistic Education, 10, 12-23.

28. Ștefănescu, M. (2015). Arta desenului. Studiul portretului și al corpului uman după model. Iași: Artes. 